\title{
On Effort and Achievement of Business Undergraduate and Graduate Students under a Disastrous Event
}

\author{
Wai Yin Mok ${ }^{1}$, Jonathan Rex Mok ${ }^{2} \&$ Kit Yee Cheung ${ }^{1}$ \\ ${ }^{1}$ College of Business Administration, University of Alabama in Huntsville, Huntsville, Alabama, USA \\ ${ }^{2}$ School of Law, University of Alabama, Tuscaloosa, Alabama, USA \\ Correspondence: Wai Yin Mok, College of Business Administration, University of Alabama in Huntsville, \\ Huntsville, Alabama, 35899, USA. Tel: 1-256-824-6980. E-mail: mokw@uah.edu
}

\author{
Received: February 4, $2016 \quad$ Accepted: March 23, $2016 \quad$ Online Published: August 29, 2016 \\ doi:10.5539/ies.v9n9p230 URL: http://dx.doi.org/10.5539/ies.v9n9p230
}

\begin{abstract}
The 2011 tornado event in Alabama left college students with a choice to be exempt of their final examinations or participate in an attempt to improve their overall grades. This incident provided an opportunity to conduct an observational study with the goal of measuring the academic effort of business undergraduate and graduate students. The observation methodology utilized total enrollment of 3804 with an undergraduate enrollment of 3298 and a graduate enrollment of 506 for the spring term of 2011 which included 969 undergraduates and 276 graduates. A stratified random sampling was used to collect enrollment data according to 8 disciplines within the business college. Findings of this study suggest graduate students outperform undergraduate students in grade improvement. In fact, the eligibility rate and successful rate for obtaining a higher grade after taking a final examination for both undergraduates and graduates were statistically insignificant. However, the participation rate for taking the final examination between undergraduates and graduates was statistically different.
\end{abstract}

Keywords: disastrous event, undergraduate and graduate students

\section{Introduction and Situation}

On April 27, 2011, a tornado outbreak devastated a large section of the state of Alabama, causing widespread power outages and record-breaking damages which forced the University of Alabama in Huntsville to halt operation for weeks. This disaster interfered with the final examinations scheduled for the spring term of 2011. Given the extent of the disaster, the provost suspended the scheduled final examinations and issued a new final examination policy.

This new policy allowed students to accept their letter grades as of April 27th with no further action required on their part, or to complete the remaining coursework by taking their final examinations scheduled later in May. To assist students in their decision making process, grades were posted on the university's online notification system to allow students to make an informed decision as to whether or not to participate in any final examination and to be aware of the scores they needed to obtain the grades they desired.

This new final examination policy made this observational study of business students' academic effort and achievement possible. In this unique circumstance, the following two survey questions were conducted to measure student effort: the first evaluated the percentage of students which chose to participate in taking a final examination and the second evaluated the percentage of students which could raise their grades by doing so. Both survey questions were comparatively used to investigate student effort and achievement under a unique stressful circumstance.

\section{Literature Review}

Within the education literature, effort and achievement has been evaluated as related factors. Various studies (Pace, 1982; Natriello \& McDill, 1986; Johnson, Crosnoe, \& Elder, 2001; Rovan, 2012) have quantified a positive linear relationship between students' effort and achievement. Pace (25 May 1982) conducted a study based on a survey collected on 12,000 undergraduate students from 40 different colleges over a 3-year period. Pace (25 May 1982) found that quality of effort is directly correlated with achievement and concluded that the key factor for achievement is the individual student's actions, not which college they attended or what subject they studied. Further research of these studies evaluates the possibility that students' effort on learning fosters 
comprehension and intelligence, which eventually leads to achievement. Carol S. Dweck and her colleagues have substantiated that quality learning effort can result in positive outcomes and foster development of intelligence over time, which will eventually lead to higher achievement. This growth mindset theory, as it has been termed, is similar to the education belief that people have the capacity to learn and change (Illovsky, 2010). The process of learning and changing can be substantiated by the functional neuroimaging of the brain (Linden, 2006; Zhao et al., 2003).

With effort being established as one of the main factors that contribute to students' achievement, the question of whether different student groups exert different levels of effort becomes important in understanding student performance. A study by R. W. Lindner and Others in 1996 examined and compared self-regulated learning related to achievement-this being degree completion-of undergraduate and graduate students. The results indicated that graduate students scored higher than undergraduate students on the five subscales of the self-regulated learning model of metacognition, learning strategies, motivation, contextual sensitivity, and environmental utilization/control with metacognition being the most distinctive area between the two groups. These results suggest that graduate students consciously decide to utilize all available means and exert much greater effort to accomplish an academic goal than undergraduate students. To echo the findings of Lindner on effort differences between undergraduate and graduate students, a study by Fish in 2013 showed that graduate students performed better on online homework than undergraduate students. In most cases, graduate students recorded a higher GPA than undergraduate students.

The understanding of the psychological aspects of undergraduate and graduate students may provide some explanations accounting for the differences in self-regulated learning in these two groups of students. A recent study by Illovsky in 2010 comparing psychological traits between undergraduate and graduate education students indicated that graduate students scored higher in the areas of achievement, harm avoidance, understanding, and desirability than undergraduate students. Due to this, there is a general consensus among educators that graduate students demonstrate a more positive view about learning and achievement than undergraduate students. In addition, a study by Menchaca-Lopez in 2014 indicated that graduate students demonstrated knowledge and the ability to respond to intervention better than undergraduate students.

Independent research has also been conducted of students' academic effort when faced with a partially completed task. Observing elementary and middle school students, these studies have evaluated the correlation between students' preference and assignment choice. The studies have shown, all else being equal, that students tend to choose tasks or assignments that require less effort (e.g., Billington et al., 2004; Friman, 1995; Hawthorn-Embree et al., 2010; Hawthorn-Embree et al., 2011; Parkhurst et al., 2011). Parkhurst et al. (2011) indicated that leisure was the most significant factor in the Multidimensional Work Ethic Profile (MWEP) when determining students' preference on assignment choice. The findings concluded that students tend to choose tasks or assignments that require the least time to finish and subsequently leave the most time to relax. Hawthorn-Embree et al. (2010) compared students' assignment choice between completing a partially completed task and undertaking a completely new task. The study showed that when the new task involves comparatively $10 \%$ less work than the partially completed task, students tend to choose the new task. However, partially completed task preference has not been evaluated among college students.

Stress has also been evaluated with regard to undergraduate and graduate students' mental health in several comparative studies. Research has shown a general rise of mental health issues in terms of prevalence and severity among university students (Gallagher, 2011) with depression and anxiety affecting $16 \%$ of undergraduate and 13\% of graduate students (Eisenberg et al., 2007). According to the Fall 2009 American College Health Association-National College Health Assessment, researchers found that stress levels are higher in undergraduates than graduates (Wyatt \& Oswalt, 2013). Further comparisons of the two groups indicated that the number of first year college students being frequently overwhelmed was increasing (Sax, 1997, 2003). A recent study of approximately 3100 graduate students found that $44.7 \%$ reported experiencing an emotional or stress-related problem during the previous 12 months (Hyun et al., 2006). Implications of such findings include decreased academic effort and performance of those groups affected by particularly high levels of stress. Directors of the National Survey of Counseling Center reported that $37.4 \%$ of students seeking campus counseling services have serious psychological problems, with approximately $5.9 \%$ so serious that they cannot remain in school or can only do so with extensive psychological/psychiatric assistance and $31.2 \%$ experience severe problems but are able to remain on campus if utilizing available treatment methods (Gallagher, 2011). With stress already prevalent in collegiate student bodies, the addition of a unique stressful event will further exacerbate these findings, thus prompting further study of effects and possible treatments. 


\section{Observation and Method}

This study used stratified random sampling to gather data through two survey questions, which were sent via emails and personal contact to the faculty of each discipline of the College of Business Administration. Each discipline was classified as a stratum and there were 8 stratums in the population. A main reason for using this sampling technique is that the elements within each stratum were homogeneous; and as a whole the strata provided a close representation of the entire business student population of 1245 in the spring semester of 2011. To test whether the sample sizes of both survey questions were within the acceptable range, sample size statistical calculations were performed (see Appendix A). The result indicated that the sample sizes of both survey questions were indeed adequate.

The response rate of the first survey question was $36.75 \%$ whereas the second survey question was $13.93 \%$, which was lower than that of the first survey question. Primarily, this is due to the fact that faculty needed to calculate three separate categories: first, the current standing of each student to determine the number of students who were eligible for moving up a letter grade if the student would take the final examination; second, the number of eligible students who took the final examination and lastly the number of students who succeeded in doing so. That required more in-depth calculation, which discouraged faculty from responding. The response rates from all stratums for the first and second survey questions are respectively shown in Tables 1 and 2.

Table 1. Enrollment data for the first survey question

\begin{tabular}{lccccc}
\hline Discipline $\dagger$ & No. of classes & $\begin{array}{c}\text { Population } \\
\text { enrollment }\end{array}$ & $\begin{array}{c}\text { No. of classes } \\
\text { reported to the } \\
\text { first survey } \\
\text { question }\end{array}$ & $\begin{array}{c}\text { Enrollment in } \\
\text { reported classes }\end{array}$ & $\begin{array}{c}\text { Percentage of } \\
\text { enrollment in } \\
\text { reported classes }\end{array}$ \\
\hline ACC* & 35 & 667 & 16 & 338 & $50.67 \%$ \\
BLS & 4 & 178 & 1 & 51 & $28.65 \%$ \\
ECN & 12 & 405 & 5 & 241 & $59.51 \%$ \\
FIN & 14 & 307 & 1 & 28 & $9.12 \%$ \\
IS & 28 & 509 & 9 & 289 & $56.78 \%$ \\
MGT & 33 & 948 & 13 & 366 & $38.61 \%$ \\
MKT & 16 & 405 & 2 & 39 & $9.63 \%$ \\
MSC & 7 & 385 & 1 & 46 & $11.95 \%$ \\
\hline Overall & 149 & 3804 & 48 & 1398 & $36.75 \%$ \\
\hline
\end{tabular}

$\dagger$ †CC: Accounting

BLS: Business Legal Studies

ECN: Economics

FIN: Finance

IS: Information Systems

MGT: Management

MKT: Marketing

MSC: Management Science

*The response of one of the accounting faculty members was not included because the final examinations of her classes were optional. Interestingly, her classes had the most students participated in the final examinations. Her submitted data was as follows:

Class Enrollment No. of students participated in the final examination

Acc 211-02 $\quad 44$

Acc 211-03 $40 \quad 9$

Acc 310-01 $52 \quad 21$ 
Table 2. Enrollment data for the second survey question

\begin{tabular}{lccccc}
\hline Discipline & $\begin{array}{c}\text { No. of } \\
\text { classes }\end{array}$ & $\begin{array}{c}\text { Population } \\
\text { enrollment }\end{array}$ & $\begin{array}{c}\text { No. of classes reported } \\
\text { to the second survey } \\
\text { question }\end{array}$ & $\begin{array}{c}\text { Enrollment in } \\
\text { reported classes }\end{array}$ & $\begin{array}{c}\text { Percentage of } \\
\text { enrollment in reported } \\
\text { classes }\end{array}$ \\
\hline ACC & 35 & 667 & 5 & 69 & $10.34 \%$ \\
BLS & 4 & 178 & 0 & 0 & $0.00 \%$ \\
ECN & 12 & 405 & 1 & 53 & $13.09 \%$ \\
FIN & 14 & 307 & 1 & 28 & $9.12 \%$ \\
IS & 28 & 509 & 6 & 166 & $32.61 \%$ \\
MGT & 33 & 948 & 4 & 129 & $13.61 \%$ \\
MKT & 16 & 405 & 2 & 39 & $9.63 \%$ \\
MSC & 7 & 385 & 1 & 46 & $11.95 \%$ \\
Overall & 149 & 3804 & 20 & 530 & $13.93 \%$ \\
\hline
\end{tabular}

Second, the number of business students of the 2011 spring semester was 1245, consisting of 969 undergraduate students and 276 graduate students. Gender, age, ethnicity, and GPA of the students are shown in Table 3. Although gender does not seem to be a contributing factor for the differences between undergraduates and graduates, other more significant factors appear to be such as: (1) age: the median age of the undergraduate students was early 20 s and that of the graduate students was late 20 s, (2) ethnicity: the percentage of White graduate students was greater than that of White undergraduate students but the opposite was true for African Americans, and (3) GPA: business graduates had higher GPA than undergraduates, as indicated in the table.

Table 3. Gender, age, ethnicity, age and GPA of business undergraduate and graduate students

\begin{tabular}{lll}
\hline & Undergraduate & Graduate \\
\hline Male & 495 & 157 \\
Female & 474 & 119 \\
Median Age & 22 & 29 \\
White & $643(66.36 \%)$ & $210(76.09 \%)$ \\
African American & $176(18.16 \%)$ & $24(8.70 \%)$ \\
Hispanic/American Indian/Alaskan & $30(3.10 \%)$ & $11(3.99 \%)$ \\
Asian/Pacific Islander & $34(3.51 \%)$ & $9(3.26 \%)$ \\
Nonresident Alien & $55(5.68 \%)$ & $17(6.16 \%)$ \\
Unknown & $31(3.20 \%)$ & $5(1.81 \%)$ \\
GPA & 3.01 & 3.64 \\
Head Count & 969 & 276 \\
\hline
\end{tabular}

*This category includes Hispanic, Asian/Pacific Islander, American Indian/Alaskan, Nonresident Alien and Unknown.

Third, the study used enrollment data as the basis for the survey questions, not student counts. Each incident of enrollment and final examination participation was considered as an independent count despite the fact that a single student might enroll in multiple classes and participate in multiple final examinations. The basis for this counting method is that a student's identity is protected under the 1971 Family Rights and Privacy Act and the 2008 Higher Education Opportunity Act. Hence, it is impossible to know the classes in which a student is enrolled. In addition, the score earned for each class in which a student enrolled before final examination is not likely to be exactly similar. Therefore, each examination decision reflects a unique behavior stemming from varied circumstances despite involving the same individual. As a result, the statistics based on enrollment and final examination participation incidents provide a more accurate picture of how a student responds to varied 
circumstances and corresponding decisions. It also allows exploring the situation that leads to a decision rather than focusing on an individual count.

\subsection{Findings and Statistical Analysis}

This section presents the data collected for the first and the second survey questions and the findings and statistical analysis thereof. Recall that the first survey question asked for the number of students who participated in the final examinations. Table 4 shows the number of undergraduate and graduate students of each discipline who participated in the final examinations.

Table 4. Total business undergraduate and graduate students participated in final exams of various disciplines

\begin{tabular}{|c|c|c|c|c|c|c|}
\hline Discipline & $\begin{array}{l}\text { No. of } \\
\text { classes }\end{array}$ & $\begin{array}{l}\text { Population } \\
\text { enrollment }\end{array}$ & $\begin{array}{l}\text { No. of } \\
\text { reported } \\
\text { classes }\end{array}$ & $\begin{array}{l}\text { Enrollment in } \\
\text { reported } \\
\text { classes }\end{array}$ & $\begin{array}{c}\text { No. of } \\
\text { students } \\
\text { participated } \\
\text { in final } \\
\text { exams }\end{array}$ & $\begin{array}{l}\text { Final exam } \\
\text { participation } \\
\text { rate }\end{array}$ \\
\hline \multicolumn{7}{|c|}{ Undergraduate } \\
\hline $\mathrm{ACC}$ & 23 & 570 & 10 & 268 & 35 & $13.06 \%$ \\
\hline BLS & 3 & 165 & 1 & 51 & 7 & $13.73 \%$ \\
\hline $\mathrm{ECN}$ & 11 & 405 & 5 & 241 & 12 & $4.98 \%$ \\
\hline FIN & 8 & 264 & 1 & 28 & 5 & $17.86 \%$ \\
\hline IS & 19 & 450 & 8 & 277 & 14 & $5.05 \%$ \\
\hline MGT & 20 & 766 & 6 & 254 & 0 & $0.00 \%$ \\
\hline MKT & 10 & 344 & 2 & 39 & 0 & $0.00 \%$ \\
\hline MSC & 6 & 334 & 1 & 46 & 0 & $0.00 \%$ \\
\hline Overall & 100 & 3298 & 34 & 1204 & 73 & $6.06 \%$ \\
\hline \multicolumn{7}{|l|}{ Graduate } \\
\hline $\mathrm{ACC}$ & 12 & 97 & 6 & 70 & 14 & $20.00 \%$ \\
\hline BLS & 1 & 13 & 0 & 0 & 0 & N/A \\
\hline $\mathrm{ECN}$ & 1 & 0 & 0 & 0 & 0 & N/A \\
\hline FIN & 6 & 43 & 0 & 0 & 0 & $\mathrm{~N} / \mathrm{A}$ \\
\hline IS & 9 & 59 & 1 & 12 & 1 & $8.33 \%$ \\
\hline MGT & 13 & 182 & 7 & 112 & 3 & $2.68 \%$ \\
\hline MKT & 6 & 61 & 0 & 0 & 0 & N/A \\
\hline MSC & 1 & 51 & 0 & 0 & 0 & N/A \\
\hline Overall & 49 & 506 & 14 & 194 & 18 & $9.28 \%$ \\
\hline
\end{tabular}

To answer the question whether the participation rate of the business graduate students was statistically greater than that of business undergraduate students of spring 2011, we conducted a 2-proportion Z-test and the results are as follows: $z$-score $=1.68$ and $p$-value $=0.046$ (see Appendix B). Since the $p$-value is less than $5 \%$, at the $95 \%$ confidence level the percentage of the business graduate students who participated in the final examinations was statistically greater than that of the business undergraduate students of spring 2011.

While the first survey question was concerned about the final examination participation rates of business undergraduates and graduates, it did not address the issue that not all students were eligible to improve their grades by participating in final examinations. Hence, to further investigate the relationship between effort and achievement, the second survey question was designed to gather data on the number of eligible students who were able to improve their grades by participating in the final examinations, the number of eligible participants who chose to participate in the final examinations, and the success rate of those eligible participants. Table 5 shows the collected data. 
Table 5. Total undergraduate and graduate eligible students, eligible participants and successful participants

\begin{tabular}{|c|c|c|c|c|c|}
\hline $\begin{array}{l}\text { Course } \\
\text { No./Section } \\
\text { No. }\end{array}$ & Enrollment & $\begin{array}{c}\text { No. of } \\
\text { eligible } \\
\text { students }\end{array}$ & $\begin{array}{c}\text { Eligible } \\
\text { student rate }\end{array}$ & $\begin{array}{c}\text { No. of eligible } \\
\text { participants in final } \\
\text { exams }\end{array}$ & $\begin{array}{l}\text { No. of successful } \\
\text { participants for an } \\
\text { improved grade }\end{array}$ \\
\hline \multicolumn{6}{|l|}{ Undergraduate } \\
\hline ACC 441 & 20 & 7 & $35.00 \%$ & 0 & 0 \\
\hline ACC 432 & 8 & 2 & $25.00 \%$ & 1 & 1 \\
\hline ECN 143 & 53 & 8 & $15.09 \%$ & 3 & 3 \\
\hline FIN 461 & 28 & 15 & $53.57 \%$ & 5 & 3 \\
\hline IS 210 & 37 & 3 & $8.11 \%$ & 0 & 0 \\
\hline IS 310 & 31 & 5 & $16.13 \%$ & 2 & 2 \\
\hline IS 301-01 & 35 & 1 & $2.86 \%$ & 0 & 0 \\
\hline IS $301-02$ & 34 & 1 & $2.94 \%$ & 0 & 0 \\
\hline IS 477 & 17 & 3 & $17.65 \%$ & 0 & 0 \\
\hline MGT 301-03 & 45 & 5 & $11.11 \%$ & 0 & 0 \\
\hline MGT 401 & 44 & 11 & $25.00 \%$ & 0 & 0 \\
\hline MKT 343 & 1 & 0 & $0.00 \%$ & 0 & 0 \\
\hline MKT 480 & 38 & 8 & $21.05 \%$ & 0 & 0 \\
\hline MSC 385-02 & 46 & 0 & $0.00 \%$ & 0 & 0 \\
\hline Overall & 437 & 69 & $15.79 \%$ & 11 & 9 \\
\hline \multicolumn{6}{|l|}{ Graduate } \\
\hline ACC 541 & 6 & 1 & $16.67 \%$ & 0 & 0 \\
\hline ACC 532 & 4 & 1 & $25.00 \%$ & 1 & 1 \\
\hline ACC 602 & 31 & 4 & $12.90 \%$ & 3 & 3 \\
\hline IS 577 & 12 & 2 & $16.67 \%$ & 1 & 1 \\
\hline MGT 501 & 13 & 2 & $15.38 \%$ & 0 & 0 \\
\hline MGT 600 & 27 & 5 & $18.52 \%$ & 3 & 2 \\
\hline Overall & 93 & 15 & $16.13 \%$ & 8 & 7 \\
\hline $\begin{array}{l}\text { Combined } \\
\text { Overall }\end{array}$ & 530 & 84 & $15.85 \%$ & 19 & 16 \\
\hline
\end{tabular}

Table 5 indicates that the eligibility rates of the business undergraduate and graduate students were respectively at $15.79 \%=69 / 437$ and $16.13 \%=15 / 93$. To test whether they were statistically different, a 2-proportion Z-test at the 0.05 level of significance was conducted (see Appendix C). The results are as follows: $z$-score $=0.0814$ and $p$-value $=0.4676$. Since the $p$-value is greater than $5 \%$, at the $95 \%$ confidence level the eligibility rates of the business undergraduate and graduate students were not statistically different.

The participation rates of those eligible undergraduate and graduate students were respectively at $15.94 \%=$ $11 / 69$ and $53.33 \%=8 / 15$. A similar 2-proportion Z-test was conducted to verify whether these two percentages were statistically different. The resulting $z$-score is 3.137 , and the $p$-value is 0.000853 , which is less than 0.05 . Hence, the participation rates of those eligible undergraduate and graduate students were shown to be statistically different.

As for the undergraduate and graduate students who successfully moved up to a next letter grade, the success rates of these two groups of students were respectively at $81.82 \%=9 / 11$ and $87.50 \%=7 / 8$. A similar 2-propoertion Z-test was again used to verify whether there was a statistical difference. The results are that the $z$-score is 0.3353 and the $p$-value is 0.7374 , which is greater than 0.05 . This means that the test did not show any statistical difference. 


\section{Discussion and Implication}

Implications of this study extend current research on student effort. Students tend to prefer assignments or partially completed assignments that require less work. This study extends the work of Hawthorn-Embree et al. (2010), Hawthorn-Embree et al. (2011), and Parkhurst et al. (2011), which involved students from elementary to middle school, by observing a more mature sample of undergraduate and graduate students. The results indicated that under a unique stressful circumstance $6.06 \%$ of business undergraduate students and $9.28 \%$ of business graduate students, which are statistically different (see Appendix B), chose to complete the course through a final examination over a reduced-to-zero effort option. These results indicate over $90 \%$ of college students remained at status quo instead of completing the final task of the course. Graduate students demonstrated significantly more effort to complete a partially completed task than undergraduates.

Various studies have shown a positive relationship between effort and achievement. This study shows that the relationship is still valid under an added stressful condition. In this study $81.82 \%$ of undergraduate final examination participants and $87.50 \%$ of graduate final examination participants succeeded in one letter grade improvement after taking the final examinations, which are not statistically different (see Appendix C). The participation rates of the eligible undergraduates and graduates showed a statistically significant difference at $15.94 \%$ and $53.33 \%$ respectively (see Appendix C). The final examination participation rate of graduate students was almost triple that of undergraduate students, but the achievement level of both groups was similar. This disparity in participation rates partially explains why the average GPA of graduate students (3.64) is higher than that of undergraduate students (3.01). Therefore, within the context of this study, the key difference between undergraduates and graduates is effort, not achievement. This finding suggests that business graduate students are more result driven and likely to exert effort for an improved reward than business undergraduate students. If both groups exerted the same level of effort, it can be expected that a similar level of achievement would be accomplished by both groups, with this being contrary to most educator's perception that graduates outperform undergraduates in assignments and examinations.

Analysis of characteristic differences between business undergraduate and graduate students showed that median age and ethnicity differences between both groups are statistically significant (see Appendix D). Median ages of undergraduates and graduates are 22 and 29, respectively, thus representing two separate generations: GEN Y and GEN X (Hansen \& Leuty, 2012). Age influences the attitude of work effort to some degree among generations; but, the continued changes in technology, population and resources make it difficult for equivalent comparisons among generations (Meriac, Woehr, \& Banister, 2010). However, a general trend suggests leisure increased steadily over the generations and work centrality declined (Twenge et al., 2010). Generation Y also places leisure above extrinsic and intrinsic values (Schullery, 2013). That partially explains why graduates work harder than undergraduates due to the significant age difference of the two groups.

The other characteristic distinction between these two groups is the racial profile of undergraduates and graduates. This included the ratios among White, African American, Asian, Hispanic/American Indian/Alaskan, Nonresident Alien and Unknown. Although the percentages of Asian, Hispanic/American Indian/Alaskan and Nonresident Alien between undergraduates and graduates are similar, there was a significant increase of White students and a decrease of African American students in the graduate level. While studies have shown African American and Hispanic students are still underrepresented in colleges (Kinzie et al., 2008; Walpole et al., 2002; Criddle-Straugheter \& Akladios, 2011), the African American undergraduate students were well represented at $18.16 \%$ and the White undergraduate students were represented at $66.36 \%$ in this study, which is average within the general population. However, African American graduate students were underrepresented at $8.7 \%$ whereas White graduate students were overrepresented at $76.09 \%$. Nevertheless, this discrepancy is insufficient to indicate the effort gap between undergraduates and graduates due to the fact that the identities of all final examination participants were protected by the 1971 Family Rights and Privacy Act. Therefore, the correlation between racial percentages and levels of exerted effort was inconclusive due to the lack of racial profile data of all final examination participants; even though, the percentages between White and African American undergraduates and graduates were statistically different (see Appendix D).

The acute onset of stress caused by the severe weather on April 27th, 2011, may be another link for the difference in participation of final examinations between undergraduates and graduates. Three EF4 tornadoes and around twenty EF1 tornadoes touched down within fifty miles of the university on that day and with $80 \%$ of the university's students living within thirty miles of the campus (see http://www.uah.edu/provost/offices/oir), a majority of students surveyed were directly or indirectly impacted by the tornadoes. This translates to a significant portion of the student population suffering from mild to severe psychological effects of a disaster; the most common of which is Post Traumatic Stress Disorder (PTSD), followed by depression and anxiety (see 
National Center for PTSD). Since undergraduates are less equipped to cope with stress than graduates (Eisenbery et al., 2007;Wyatt \& Oswalt, 2013); it is expected that this added stress impacted undergraduates' academic performance more negatively than graduates.

This study indicated that it is the level of effort that separates undergraduate from graduate students, with graduate students more likely to exert more effort than undergraduate students. With this being the case, educators can address needs of both groups separately. Undergraduates likely represent generation $\mathrm{Y}$ and thus are prone to think visually, want immediate gratification, and emphasize fun and excitement (Josiam et al., 2009). They tend to utilize collaboration tools (technological devices) to solve problems and shorten the learning curve (Bradley, 2007). Faculty may design assignments with more direct applications, utilize more visual materials, and facilitate more interaction through technological devices to encourage undergraduates' participation. Also, immediate feedback and extra credit opportunities may encourage more undergraduate effort. Graduate courses need not be as much individual detail instruction, but can focus more on academic goals for students to achieve.

The above implications of exerting effort between business graduate and undergraduate students can possibly carry over in a similar trend in the workplace. Workers with graduate degrees may exhibit higher effort and self-efficacy than those with only bachelor's degrees under stressful circumstances. With this being the case, graduate students as a whole in the workforce may have a more advantageous position than undergraduate students. According to the 2009 job survey conducted by the National Association of Colleges and Employers (English et al., 2012), communication skills, both verbal and written, and a strong work ethic are the first two qualities needed for new recruits. Furthermore, the positive effort behavior of graduate students observed by this study may translate into enhanced occupational competency and increased employee productivity, even during periods of unique stressful circumstances.

Lastly, studies by Hailikari et al. (2008), Diseth et al. (2010), Hemmings and Kay (2010), and Martin et al. (2013), have indicated that prior academic achievement has a predictive value for future academic performance among grade school students and college students. This study echoes a similar hypothesis in college students. Our findings indicated that $15.79 \%$ of undergraduates and $16.13 \%$ of graduates were eligible to move up to a letter grade if final examinations were taken. The illegibility rates of undergraduates $(84.21 \%)$ and graduates (83.87\%) represented students who could not move up to a letter grade even if they had scored $100 \%$ correct on final examinations. It suggests that prior (or cumulative) achievement before final examinations not only has a predictive value; it is a prerequisite for students to improve their current status. In other words, prior (or cumulative) achievement restricts students' further achievement.

\section{Limitations}

This study was limited to students from the College of Business Administration of the University of Alabama in Huntsville. It would be a more comprehensive study if other colleges of the university were included, which would better represent the general population. Students from other colleges may not respond in the way that business students did. A comparison of students' responses from different colleges may enhance our understanding of students' behavior on effort and achievement under a stressful situation.

The observational study of this paper investigated business students' decision made under a unique circumstance. Although their decisions reflected academic effort, this study did not consider the intellectual and nonintellectual variables that lead to their decision preference. It would be beneficial to conduct follow-up studies to investigate the various aspects of how business undergraduate and graduate students evaluate and decide what measure of work to put forth in a unique stressful event. The use of Multidimensional Work Ethic Profile proposed by Miller, et al. (2002) and a personality measure, such as NEO-FFI five factors model proposed by Costa and McCrae, for both groups of students to complete could provide understanding on their behavior dynamic. The information of students' ACT or SAT scores can serve as a benchmark for an intellectual variable of business undergraduate and graduate students. It may yield important insights on decision making behavior. Most importantly, further findings may suggest and postulate any differences between business undergraduate and graduate students in their value of work and work performance in their career path.

The disastrous event on April 27th, 2011, posed additional stress to the students at the University of Alabama in Huntsville. We understand that undergraduates may be affected by the disastrous event somewhat more than graduates. The degree to which the additional stress and hardship influences both groups of students' decision-making preference needs to be further investigated. A similar study is being conducted by Professor James Hamilton, called the "Silver Lining Project," which is investigating the effects of the tornado outbreak of April 27, 2011, in Tuscaloosa on overall students' adjustment. The goals of the study are to identify the effects of the disaster and to pinpoint the psychological mechanisms that trigger such effects. It may widen our 
understanding of how students cope with disastrous situations and continue to function to finish their academic work.

The business undergraduates of this study belong to the newest generation: generation $\mathrm{Y}$ or the millennial generation. The most noticeable differences of the millennial generation are their technological aptitude (Reisenwitz \& Iyer, 2009) and their sense of entitlement (Schullery, 2013). Also, they exhibit more needs for counseling and more episodes of psychological distress (Sax, 1997, 2003; Gallagher, 2011). Technological aptitude and entitlement may promote counterproductive behavior and encourage a less effort approach to study that may deter them from reaching their potential. The higher level of stress experienced by this group of students may hinder their academic performance. Therefore, further research could focus on formulating and verifying a hypothesis about how technological aptitude, entitlement and stress level of the millennial generation are related to positive or negative effects of achievement.

\section{Conclusions}

Business graduate students demonstrated a higher level of work effort and stamina than undergraduate students under a disaster event with implications of a possible continuous trend in the workplace. This study also suggests that the academic achievement gap between graduates and undergraduates could be mitigated by the level of exerted effort.

\section{References}

Ben-Porath, Y. S., \& Waller, N. G. (1992). Five big issues in clinical personality assessment: A rejoinder to Costa and McCrae. Psychological Assessment, 4(1), 23-25. http://dx.doi.org/10.1037/1040-3590.4.1.23

Billington, E. J., Skinner, C. H., Hutchins, H. M., \& Malone, J. C. (2004). Varying Problem Effort and Choice: Using the Interspersal Technique to Influence Choice towards More Effortful Assignments. Journal of Behavioral Education, 13(3), 193-207. http://dx.doi.org/10.1023/B:JOBE.0000037629.97526.ab

Blackwell, L., Trzesniewski, K. H., \& Dweck, C. S. (2007). Implicit Theories of Intelligence Predict Achievement Across an Adolescent Transition: A Longitudinal Study and an Intervention. Child Development, 78(1), 246-263. http://dx.doi.org/10.1111/j.1467-8624.2007.00995.x

Bradley, M. (2007). Training the next generation. Systems Contractor News, 12(14), 48.

Costa, P. R., \& McCrae, R. (n.d). The NEO Personality Inventory.

Criddle-Straughter, K., \& Akladios, M. (2011). Factors Affecting Grade Variation between Graduate \& Undergraduate Students. Journal of Safety, Health \& Environmental Research, 7(1), 16.

Diseth, A. (2011). Self-Efficacy, Goal Orientations and Learning Strategies as Mediators between Preceding and Subsequent Academic Achievement. Learning and Individual Differences, 21(2), 191-195. http://dx.doi.org/10.1016/j.lindif.2011.01.003

Diseth, A., \& Kobbeltvedt, T. (2010). A Mediation Analysis of Achievement Motives, Goals, Learning Strategies, and Academic Achievement. British Journal of Educational Psychology, 80(4), 671-687. http://dx.doi.org/10.1348/000709910X492432

Diseth, Å., Pallesen, S., Brunborg, G., \& Larsen, S. (2010). Academic Achievement among First Semester Undergraduate Psychology Students: The Role of Course Experience, Effort, Motives and Learning Strategies. Higher Education, 59(3), 335-352. http://dx.doi.org/10.1007/s10734-009-9251-8

Dweck, C. S. (2010). Even Geniuses Work Hard. Educational Leadership, 68(1), 16-20.

Dweck, C., \& Molden, D. (2008). Self-Theories: The Construction of Free Will. Oxford University Press. http://dx.doi.org/10.1093/acprof:oso/9780195189636.003.0004

Eisenberg, D., Gollust, S. E., Golberstein, E., \& Hefner, J. L. (2007). Prevalence and correlates of depression, anxiety, and suicidality among university students. American Journal of Orthopsychiatry, 77(4), 534-542. http://dx.doi.org/10.1037/0002-9432.77.4.534

English, D. D., Manton, E. J., Sami, A. R., \& Dubey, A. A. (2012). A Comparison of the Views of College of Business Graduate and Undergraduate Students on Qualities Needed in the Workplace. College Student Journal, 46(2), 427-435.

Fish, L. A. (2013). A Comparison of Undergraduate versus Graduate Student Perceptions and Performance using Online Homework in Introduction to Operations Management Courses. Business Education Innovation Journal, 5(1), 58-66. 
Friman, P. C., \& Poling, A. (1995). Making Life Easier with Effort: Basic Findings and Applied Research on Response Effort. Journal of Applied Behavior Analysis, 28(4), 583-590. http://dx.doi.org/10.1901/jaba.1995.28-583

Gallagher, R. (2011). National Survey of Counseling Center Directors, 2011. Monograph Series No. 8T Alexandria, VA: International Association of Counseling Services.

Hailikari, T., Nevgi, A., \& Komulainen, E. (2008). Academic self-beliefs and prior knowledge as predictors of student achievement in mathematics: A structural model. Educational Psychology, 28(1), 59-71. http://dx.doi.org/10.1080/01443410701413753

Hansen, J. C., \& Leuty, M. E. (2012). Work Values across Generations. Journal of Career Assessment, 20(1), 34-52. http://dx.doi.org/10.1177/1069072711417163

Hawthorn-Embree, M. L., Skinner, C. H., Parkhurst, J., \& Conley, E. (2011). An Investigation of the Partial-Assignment Completion Effect on Students' Assignment Choice Behavior. Journal of School Psychology, 49(4), 433-442. http://dx.doi.org/10.1016/j.jsp.2011.04.006

Hawthorn-Embree, M. L., Skinner, C. H., Parkhurst, J., O’Neil, M., \& Conley, E. (2010). Assignment Choice: Do Students Choose Briefer Assignments or Finishing What They Started? School Psychology Quarterly, 25(3), 143-151. http://dx.doi.org/10.1037/a0020914

Hemmings, B., \& Kay, R. (2010). Prior achievement, effort, and mathematics attitude as predictors of current achievement. Australian Educational Researcher, 37(2), 41-58. http://dx.doi.org/10.1007/BF03216921

Hyun, J. K., Quinn, B. C., Madon, T., \& Lustig, S. (2006). Graduate student mental health: Needs assessment and utilization of counseling services. Journal of College Student Development, 47(3), 247-266. http://dx.doi.org/10.1353/csd.2006.0030

Illovsky, M. E. (2010). Psychological Comparisons of Undergraduate and Graduate College of Education Students. International Journal of Teaching and Learning in Higher Education, 22(3), 238-245.

Johnson, M., Crosnoe, R., \& Elder, G. H., Jr. (2001). Students’ Attachment and Academic Engagement: The Role of Race and Ethnicity. Sociology of Education, 74(4), 318-340. http://dx.doi.org/10.2307/2673138

Josiam, B. M., Crutsinger, C., Reynolds, J., Dotter, T., Thozhur, S., Baum, T., \& Devine, F. G. (2009). An empirical study of the work attitudes of Generation Y college students in the USA: The case of hospitality and merchandising undergraduate majors. Journal of Services Research, 9(1), 5-30.

Kinzie, J., Gonyea, R., Shoup, R., \& Kuh, G. D. (2008). Promoting persistence and success of underrepresented students: Lessons for teaching and learning. New Directions for Teaching \& Learning, 2008(115), 21-38. http://dx.doi.org/10.1002/tl.323

Linden, D. (2006). How psychotherapy changes the brain-the contribution of functional neuroimaging. Molecular Psychiatry, 11(6), 528-538. http://dx.doi.org/10.1038/sj.mp.4001816

Lindner, R. W. et al. (1996). Are Graduate Students Better Self Regulated Learners Than Undergraduates? A Follow-Up Study.

Martin, A. J., Wilson, R., Liem, G. D., \& Ginns, P. (2013). Academic Momentum at University/College: Exploring the Roles of Prior Learning, Life Experience, and Ongoing Performance in Academic Achievement across Time. Journal of Higher Education, 84(5), 640-674. http://dx.doi.org/10.1353/jhe.2013.0029

Menchaca-Lopez, E. (2014). A study of undergraduate and graduate students' knowledge of response to intervention in a southern New Mexico college of education. Dissertation Abstracts International Section A.

Meriac, J. P., Woehr, D. J., \& Banister, C. (2010). Generational Differences in Work Ethic: An Examination of Measurement Equivalence across Three Cohorts. Journal of Business and Psychology, 25(2), 315-324. http://dx.doi.org/10.1007/s10869-010-9164-7

Miller, M. J., Woehr, D. J., \& Hudspeth, N. (2002). The Meaning and Measurement of Work Ethic: Construction and Initial Validation of a Multidimensional Inventory. Journal of Vocational Behavior, 60(3), 451-489. http://dx.doi.org/10.1006/jvbe.2001.1838

Natriello, G., \& McDill, E. L. (1986). Performance Standards, Student Effort on Homework, and Academic Achievement. Sociology of Education, 59(1), 18-31. http://dx.doi.org/10.2307/2112483

Pace, C. R. (25 May 1982). Achievement and the Quality of Student Effort. National Commission on Excellence 
in Education (ED), Washington, DC (pp. 2-40). Retrieved from http://www.learningoutcomesassessment. org/documents/CSEQ-AchievementAndTheQualityOfStudentEffort.pdf

Parkhurst, J., Fleisher, M., Skinner, C., Woehr, D., \& Hawthorn-Embree, M. (2011). Assignment choice, effort, and assignment completion: Does work ethic predict those who choose higher-effort assignments? Learning and Individual Differences, 21(5), 575-579. http://dx.doi.org/10.1016/j.lindif.2011.04.003

Reisenwitz, T. H., \& Iyer, R. (2009). Differences in Generation X and Generation Y: Implications for the Organization and Marketers. Marketing Management Journal, 19(2), 91-103.

Rovan, D. (2012). The Relationship of Effort in Learning Mathematics to Achievement Goals, Beliefs and Personality Traits. Suvremena Psihologija, 15(1), 81-95.

Sax, L. (1997). Health trends among college freshmen. Journal of American College Health, 45(6), $252-264$. http://dx.doi.org/10.1080/07448481.1997.9936895

Sax, L. J. (2003). Our Incoming Students: What Are They Like? About Campus, 8(3), 15-20.

Schullery, N. M. (2013). Workplace Engagement and Generational Differences in Values. Business Communication Quarterly, 76(2), 252-265. http://dx.doi.org/10.1177/1080569913476543

Twenge, J. M., Campbell, S. M., Hoffman, B. J., \& Lance, C. E. (2010). Generational differences in work values: Leisure and extrinsic values increasing, social and intrinsic values decreasing. Journal of Management, 36(5), 1117-1142. http://dx.doi.org/10.1177/0149206309352246

Walpole, M., Bauer, C., Gibson, C., Kanyi, K., \& Toliver, R. (2002). African American Students'Early Outcomes of College: Links between Campus Experiences and Outcomes.

Wyatt, T., \& Oswalt, S. B. (2013). Comparing Mental Health Issues Among Undergraduate and Graduate Students. American Journal of Health Education, 44(2), 96-107. http://dx.doi.org/10.1080/19325037.2013.764248

Zhao, M., Momma, S., Delfani, K., Carlen, M., Cassidy, R. M., Johansson, C. B., ... Janson, A. M. (2003). Evidence for neurogenesis in the adult mammalian substantia nigra. Proceedings of the National Academy of Sciences of the United States of America, 100(13), 7925-7930. http://dx.doi.org/10.1073/pnas.1131955100

\section{Appendix A}

To calculate the sample sizes of both survey questions, the suggested proportion of final examination participants was set at $25 \%$, which means $75 \%$ of the students chose the reduced-to-zero effort task to complete the course. This proportion benchmark was applied according to a study of partially completed course preference (Hawthorn-Embree, et al., 2010). The study indicated that $74.55 \%$ (41/55) of 7 th graders chose to finish the assignment with $10 \%$ less work than the original work required; therefore, $25.45 \%$ of students chose to complete the previous assignment. We believe the suggested proportion for final exam participants was sufficient in our study. Hence, we assume $p=25 \%$ of business students would take the optional final examinations of spring 2011 . We use the random sample formula for calculating the sample size $\mathrm{n}$ for the both survey questions:

$$
n=\left(z_{(\alpha / 2)}\right)^{2} p(1-p) / E^{2}
$$

Setting the desired margin of error $E$ to $0.04, n=(1.96) 2(.25)(.75) /(.04) 2=451$. The reported enrollments of both survey questions were 1398 and 530 respectively, which were greater than the required number of 451 . A word of caveat is that with our best effort, we still had no control on the survey response rate or the number of enrollments in each class. For the first survey question, each stratum was included in the sample; however, Finance and Marketing enrollments were slightly underrepresented because of the small class size. For the second survey question, each stratum was also included in the sample except Business Legal Studies, which was peripheral to business majors and underrepresented like Finance and Marketing.

\section{Appendix B}

Let $n_{g}$ and $n_{u}$ be the respective numbers of the graduate and undergraduate business students of spring 2011. Let $x_{g}$ and $x_{u}$ be the respective numbers of the graduate and undergraduate business students in the reported classes of the survey. Let $p_{g}=x_{g} / n_{g}$ and $p_{u}=x_{u} / n_{u}$ be the respective proportions of the graduate and undergraduate business students who participated in the final examinations of spring 2011. The null and alternative hypotheses are: 


$$
\begin{gathered}
H_{0}: p_{g}-p_{u} \leqslant 0, \\
H_{a}: p_{g}-p_{u}>0 .
\end{gathered}
$$

Assume $p_{g}=p_{u}=p$. Then, the standard error of $p_{g}-p_{u}$ is $\sqrt{ }\left(p(1-p)\left(1 / n_{g}+1 / n_{u}\right)\right)$. With $p$ unknown, the standard error of $p_{g}-p_{u}$ is estimated as $\sqrt{ }\left(p^{\prime}\left(1-p^{\prime}\right)\left(1 / n_{g}+1 / n_{u}\right)\right)$ where $p^{\prime}$ is the pooled estimator of $p$. The test statistic $z$ for hypothesis tests about $p_{g}-p_{u}$ is thus $\left(p_{g}-p_{u}\right) / \sqrt{ }\left(p^{\prime}\left(1-p^{\prime}\right)\left(1 / n_{g}+1 / n_{u}\right)\right)$. According to Table $4, p_{g}=18 / 194=0.09278, p_{u}=73 / 1204=0.06063$ and $p^{\prime}=(18+73) /(194+1204)=0.06509$. Therefore, the standard error of $p_{g}-p_{u}$ is 0.01908 . The test statistic $z$ is therefore 1.6847. As a result, the $p$-value is 0.04602 and thus $H_{0}$ is rejected at the 0.05 level of significance. Hence, at the $95 \%$ confidence level the percentage of graduate students taking the final examinations was statistically greater than that of undergraduate students.

\section{Appendix C}

Three 2-proportion Z-tests at the 0.05 level of significance were performed for the second survey question, each of which has a null and an alternative hypothesis as follows:

$$
\begin{aligned}
& H_{0}: p_{1}-p_{2}=0, \\
& H_{a}: p_{1}-p_{2} \neq 0 .
\end{aligned}
$$

Following a similar statistical procedure of Appendix B, the following results were obtained for the three Z-tests at the $95 \%$ confidence level:

\begin{tabular}{lllll}
\hline & Undergraduates & Graduates & Statistical Results & Conclusion \\
\hline Eligibility Rate & $15.79 \%=69 / 437$ & $16.13 \%=15 / 93$ & $z=0.0814$, & $\begin{array}{l}\text { No statistical } \\
\text { differences }\end{array}$ \\
& & & $p=0.4676$ & $\begin{array}{l}\text { Statistically } \\
\text { Participation Rate }\end{array}$ \\
& $15.94 \%=11 / 69$ & $53.33 \%=8 / 15$ & $p=0.137$, & different \\
Success Rate & $81.82 \%=9 / 11$ & $87.50 \%=7 / 8$ & $z=0.3353$, & $\begin{array}{l}\text { No statistical } \\
\text { differences }\end{array}$ \\
& & & $p=0.7374$ & \\
\hline
\end{tabular}

\section{Appendix D}

A standard two-sample t-test for comparing two means was conducted to verify that the average age of business graduates was statistically greater than that of business undergraduates in the spring term of 2011. The data in the following table was obtained from the Office of Institutional Research of the university.

\begin{tabular}{llll}
\hline Group & Population & Average age & Standard Deviation \\
\hline Undergraduates & 969 & 24.15 & 1.98 \\
Graduates & 276 & 32.7 & 1.29 \\
\hline
\end{tabular}

The results are as follows: $t$-value $=85.18, d f=680.8, p$-value $=0$. Therefore, at the $95 \%$ confidence level, the average age of business graduates was statistically greater than that of business undergraduates.

A Z-test similar to the one of Appendix B was conducted to verify that the proportion of White business graduates was statistically greater than that of White business undergraduates and the opposite was true for African American. For White, $z$-score $=3.07$ and $p$-value $=0.001$. For African American, $z$-score $=3.78$ and $p$-value $=0.00008$. Therefore, both assertions were statistically established.

\section{Copyrights}

Copyright for this article is retained by the author(s), with first publication rights granted to the journal.

This is an open-access article distributed under the terms and conditions of the Creative Commons Attribution license (http://creativecommons.org/licenses/by/4.0/). 